\title{
Driving forces for changes in geographic range of cattle ticks (Acari: Ixodidae) in Africa: A review
}

\author{
N. Nyangiwe ${ }^{1 \#}$, M. Yawa ${ }^{2}$ \& V. Muchenje ${ }^{2}$ \\ ${ }^{1}$ Döhne Agricultural Development Institute, Private Bag X15, Stutterheim 4930, South Africa \\ ${ }^{2}$ Department of Livestock and Pasture Science, Faculty of Science and Agriculture, University of Fort Hare, P. Bag \\ X1314, Alice 5700, South Africa
}

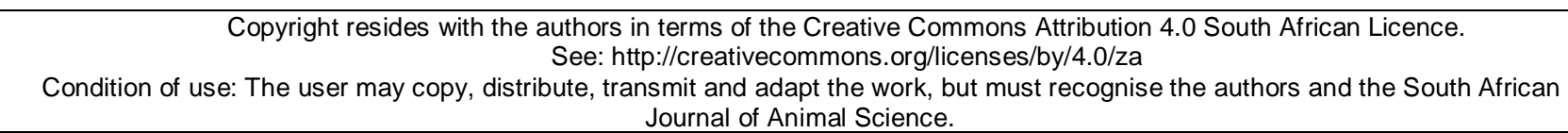

\begin{abstract}
Ticks are the most important external parasites of cattle and are known to transmit more pathogens than any other group of arthropods worldwide. About $80 \%$ of the world cattle population is at risk of ticks and tick-borne diseases, causing a global annual loss of \$US22-30 billion. In Africa, the impact of ticks is ranked high, and they transmit diseases such as cowdriosis, anaplasmosis, bovine babesiosis and theileriosis. A range expansion of ixodid ticks has been observed in Africa, in particular for the genera Amblyomma and Rhipicephalus, which contribute greatly to cattle loss owing to morbidity and mortality. Distributional changes in ticks can lead to the emergence or re-emergence of infectious and parasitic diseases. Climate change is frequently invoked as the primary cause of tick distribution, but it is not the only factor. Human lifestyle changes, including transportation of livestock within countries, have promoted the introduction of new tick species and the diseases they transmit. One such example is the spread of the Asian cattle tick Rhipicephalus (Boophilus) microplus to West Africa. Rhipicephalus (Boophilus) microplus was recorded for the first time in Namibia and was probably introduced into Namibia from South Africa. Likewise, Amblyomma variegatum, the vector of heartwater disease, has the largest distribution in Africa. Its spread is outside its native range and it is considered the second most invasive tick species after $R$. (B.) microplus on the continent. Rhipicephalus (Boophilus) microplus is a one-host tick that is reported to be resistant to conventional acaricides and this contributes largely to its spread into non-endemic areas.
\end{abstract}

Keywords: Acaricide resistance, climate change, epidemiology, range expansion, tick ecology

\# Corresponding author: nyangiwe1@gmail.com

\section{Introduction}

Ticks are hematophagous acarines, which belong to the phylum Arthropoda, class Arachnid and order Acari (Walker et al., 2003; Guglielmone et al., 2010). They are regarded as one of the leading vectors of diseases of veterinary importance to the livestock industry globally (Jongejan \& Uilenberg, 2004). Various studies have reported that ticks and tick-borne diseases (TTBDs) affect $80 \%$ of the world cattle population, particularly in tropical and subtropical countries (Ghosh et al., 2006; Ahmed et al., 2007; Marcelino et al., 2012) and cause an estimated annual loss of US\$22-30 billion (Lew-Tabor \& Rodriguez Valle, 2016). Four groups of tick-borne diseases TBDs that pose major constraints to cattle production and are of veterinary importance are cowdriosis (heartwater), anaplasmosis (gall sickness), bovine babesiosis (redwater) and theileriosis (Marcelino et al., 2012). Ticks affect domestic animals directly with non-specific symptoms such as anaemia, restlessness, dermatosis, toxicosis, paralysis, loss of condition and decrease in milk production (Jonsson, 2006).

The economically most important ixodid ticks of livestock in tropical regions belong to the genera of Amblyomma, Hyalomma and Rhipicephalus, including subgenus Boophilus (Frans, 2000). In Africa, A. hebraeum and $A$. variegatum are the vectors of Ehrlichia (Cowdria) ruminantium, which are the causative 
organisms of heartwater in cattle, sheep and goats. $R$. (B.) decolaratus, the African blue tick, is the vector of Babesia bigemina and Anaplasma marginale, while R. (B.) microplus, the Asiatic blue tick, is the vector of $B$. bovis, $B$. bigemina and $A$. marginale, the causative organisms of redwater and gall sickness in cattle. Rhipicephalus appendiculatus, the brown ear tick, transmits several species of Theileria, causing theilerioses in cattle (Norval \& Horak 2004; Madder et al., 2011). Amblyomma variegatum is established in several regions in Africa and is regarded as the second most invasive tick species after $R$. (B.) microplus (Barré \& Uilenberg, 2010). In Zimbabwe, $A$. variegatum is colonizing territories in which it was not found previously (Estrada-Peña et al., 2008; Sungirai et al., 2015). However, numerous studies have shown that cattle with smooth light-coloured short-hair coats (Nguni and Boran breeds) tend to have lower tick infestations than those with rough darker-coloured long-hair coats (Martinez et al., 2006; Muchenje et al., 2008; Katiyatiya et al., 2014). Recent studies have shown that Nguni cattle carry lower tick loads (Marufu et al., 2011; Nyangiwe et al., 2011) and therefore seem to be more resistant to ticks than Angus and Bonsmara cattle (Muchenje et al., 2008). Recently, the resistance phenotype has been linked to a delayed hypersensitivity reaction in the Nguni breed (Marufu et al., 2013) confirming the observations of Constantinoiu et al. (2010) of Holstein Friesian (a susceptible breed) and Brahman (a resistant breed) cattle.

The direct effects of ticks on their hosts include tick toxicosis, metabolic disturbances, anaemia and tick worry. All these factors can lead to production losses or deaths (Bazarusanga et al., 2007). Losses because of tick infestations can be substantial and are known to be breed-dependent with Bos indicus cattle being more resistant than $B$. taurus breeds. However, resistance can be improved through selection (Frisch, 1999; Porto Neto et al., 2011). Few studies have reported on the costs involved in tick control and the diseases they transmit, but earlier reports were in the region of US\$8.43 for plunge dipping, US\$13.62 for hand spraying and US\$21.09 for pour-on treatments per animal per year (De Castro, 1997; D'Haese et al., 1999). According to Jonsson et al. (2008), losses that can be directly ascribed to TBDs are morbidity, mortality and costs of veterinary services, including vaccines and treatment of sick animals. In Africa, losses due to TTBDs were estimated to be US\$160 million (Dold \& Cocks, 2001). As well as the large numbers of tick-related cattle deaths, over $30 \%$ of calf crop was reported to be lost because of TBDs in Uganda (Vudriko et al., 2016). Tick control is a global problem and is therefore a priority for many countries (Lodos et al., 2000). Control of tick infestations rests overwhelmingly on the use of conventional acaricides, although the disadvantages are recognised. A broad range of acaricides - including arsenical chlorinated hydrocarbons, organophosphates, carbamates, formamidines and synthetic pyrethroids - is being used to control ticks on livestock (Rajput et al., 2006; Spickett, 2013). If chemical acaricides are applied correctly, they are efficient and can be cost effective (Willadsen, 2006). In South Africa, like the rest of African countries, indigenous breeds such as Nguni are recommended for use in the integrated control of ticks (Mapiye et al., 2009; Marufu et al., 2011).

Chemical control of ticks using acaricides is often accompanied by serious drawbacks, including chemical residues in food (meat and milk products), environmental contamination, selection of acaricideresistant ticks, the expense of developing new acaricides and the difficulty of producing tick-resistant cattle while maintaining desirable production characteristics (Miller et al., 2005; Aguilar-Tipacamu et al., 2011; Abbas et al., 2014; Vudriko et al., 2016). Tick control using acaricides was viewed as one of the best methods, but it has been shown recently that ticks have developed resistance to a range of acaricides (Rajput et al., 2006). Although most reports of resistance are for Rhipicephalus (Boophilus) spp., acaricideresistant multihost ticks have been reported (Frisch, 1999). Despite the acaricide-resistance phenomenon, there has been a steady increase in the abundance and spatial distribution of economically important ticks (Sutherst, 2001; Süss et al., 2008).

The issue of climate change is a controversial debate, but from the perspective of the climate change, ticks are affected mostly because of their strong dependence on living and non-living conditions for local survival and reproduction. Climatic factors such as temperature and rainfall vary, thus corresponding changes in tick phenology, survival and development have been observed (Lindgren \& Jaenson, 2006; Gray, 2008; Ogden et al., 2008; Léger et al., 2013). Estrada-Peña \& De la Fuente (2014) refers to tick phenology as tick lifecycle events and explain how these are influenced by seasonal and inter-annual variations in weather. Tick lifecycles, in particular the larval stage, undergo specific intense interactions at the host interface, such as physiological and immunological defences. Although climate change may have huge or little impact on the spread of ticks and the associated pathogens they transmit, farmers perceive that the rapid spread of TTBDs is probably the result of transhumance (Adakal et al., 2013; Kamani et al., 2017; Nyangiwe et al., 2017). In this review article, the distribution of ticks of veterinary importance in Africa and their epidemiological implications are discussed. 


\section{Tick biology and ecology}

Ticks (Acarina: Ixodoidea) are divided into three families, namely Argasidae or soft-bodied ticks (191 species), Ixodidae or hard ticks (701) and Nuttalliellidae, which consists of only one species, Nuttalliella Namaqua (Guglielmone et al., 2010; Estrada-Peña \& De la Fuente, 2014). This review focus on the Ixodidae family, which affect the cattle industry most. About six important genera of ixodid ticks are found in Africa, including subgenus Boophilus. These are Amblyomma, Dermacentor, Haemaphysalis, Hyalomma, Ixodes and Rhipicephalus (Boophilus) (Jongejan \& Uilenberg, 2004). There are four stages in the lifecycle of an ixodid tick, namely egg, larva, nymph and adult. Unlike the argasid ticks, which mate off-host in the vegetation, ixodid ticks copulate while on their host (Horak et al., 2002). The engorged female drops to the ground and lay eggs in the soil. After three to four weeks, six-legged larvae hatch from batches of approximately 20000 eggs from the genus Amblyomma and approximately 3000 eggs from the genus Rhipicephalus, including subgenus (Boophilus). Larvae can take three to five days to fully engorge with blood, nymphs take four to eight days and females five to 20 days. When the ticks have engorged with blood, they detach from the host's skin and drop to the ground. Males of most types of ticks feed, but do not expand like the females (Latif \& Walker, 2004). For survival, each of the post-embryonic stages requires a blood meal.

Ixodid ticks undergo one-host, two-host or three-host lifecycles (Walker et al., 2003). In the one-host lifecycle, ticks remain on the same host for the larva, nymph and adult stages, leaving the host only prior to laying eggs (Figure 1). The two-host lifecycle is similar, but only the larvae and nymphs feed on the same host and the adults feed on another host. Eggs are laid in the physical environment. The second host may be the same individual as the first host, the same species, and even a second species. Three-host ticks require three animals to enable them to complete their lifecycle, because each of the two immature stages drops from the host after feeding, and moults to the next stage, with the adults feeding on a third host (Figure 2). Most ixodid ticks belong to this group, for example $A$. hebraeum and $R$. appendiculatus. The three hosts are not always the same species, but may be the same species or even the same individual, depending on host availability for the tick (Latif \& Walker, 2004).

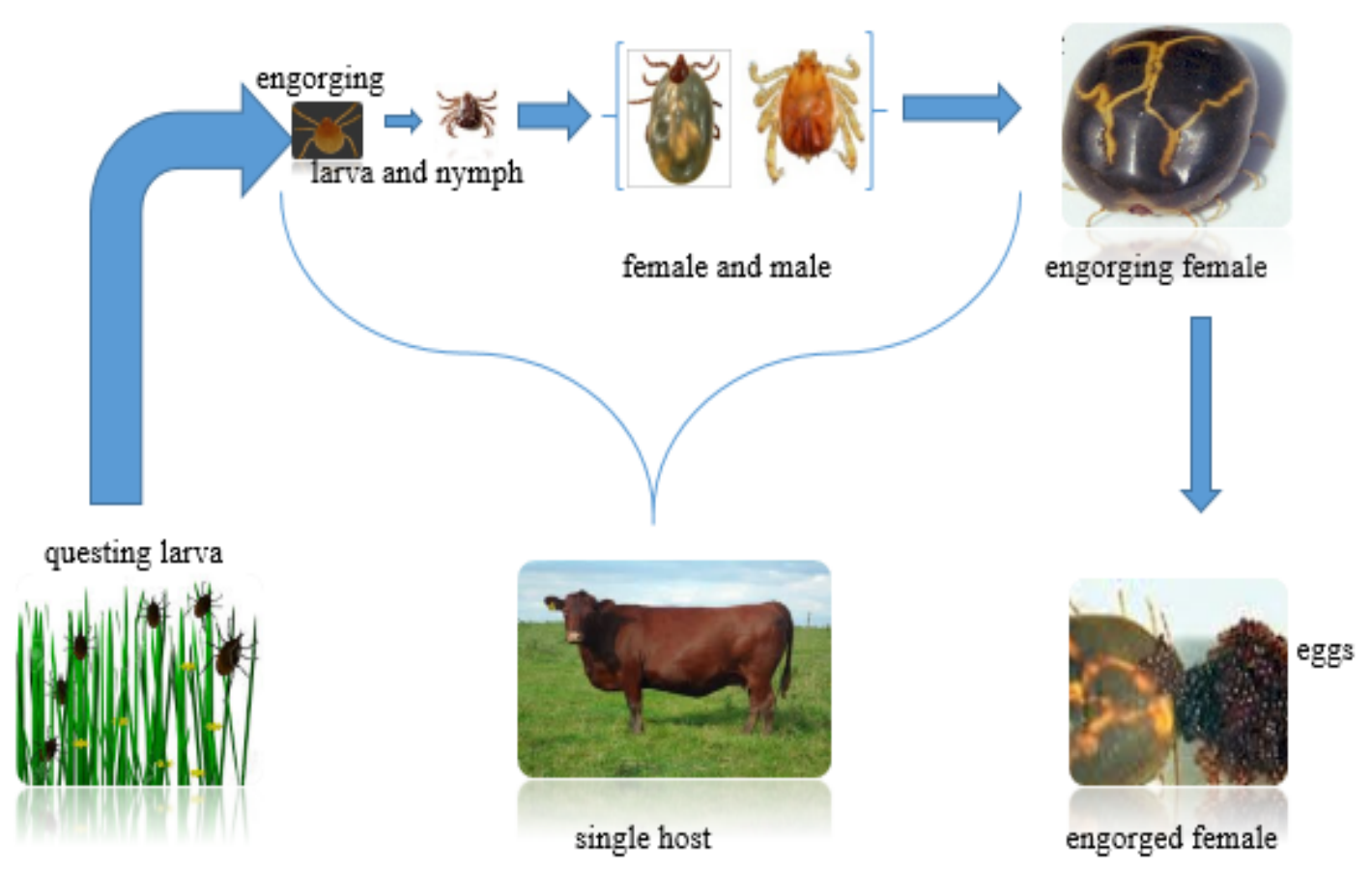

Figure 1 Lifecycle of the one-host tick

The lifecycle of one-host ticks is usually rapid. For sub-genus Boophilus it takes three weeks for feedings on one host and two months for egg laying and hatching of larvae. This lifecycle has been modified from Walker et al. (2003). 
For ticks to transmit diseases, they must be acquired from an infected host, passed into the next active stage, then successfully transmitted into a new host (Kahl et al., 2002; Estrada-Peña et al., 2013). At each blood meal, ticks can become integrated into the epidemiological chain of pathogen transmission by transstadial (stage to stage or horizontal transmission) or transovarial (female to egg, or vertical transmission) passage (Kahl et al., 2002; Estrada-Peña \& De la Fuente, 2014). Walker et al. (2003) define transovarial transmission as that which occurs when a microorganism is transmitted from one vertebrate host to another by infecting a female vector, then passing it through the eggs to the larvae. Transstadial transmission occurs when a microorganism is transmitted between vertebrate hosts by infecting one stage of the vector, then passing to the next stage of the lifecycle of the vector during moulting. When the next stage feeds, the microorganism passes to another host (Walker et al., 2003). However, transovarial transmission of Babesia spp. has been demonstrated for species of ticks such as R. (B.) microplus and R. (B.) decolaratus. Of the species that affect cattle, $B$. bovis and $B$. bigemina are the most economically important worldwide (Bock et al., 2004; World Organization for Animal Health (OIE), 2008; Terkawi et al., 2011).

For the first time Socolovschi et al. (2007) demonstrated transstadial and transovarial transmission of Rickettsia africae in naturally infected $A$. variegatum. Rickettsia africae is the causative agent of African tick bite fever, which is transmitted by hard ticks of the Amblyomma genus (Jensenius et al., 2003). A. hebraeum, a tick found in large ruminants and wildlife species, is the most common vector of $R$. africae in southern Africa. Epidemiological evidence indicates that $A$. variegatum is the predominant vector for the rest of subSaharan Africa and the West Indies (Jensenius et al., 2003; Socolovschi et al., 2007). Cattle, wild game and other ungulates are the principal hosts of the Amblyomma vectors, although larvae and nymphs may also parasitize birds and rodents.

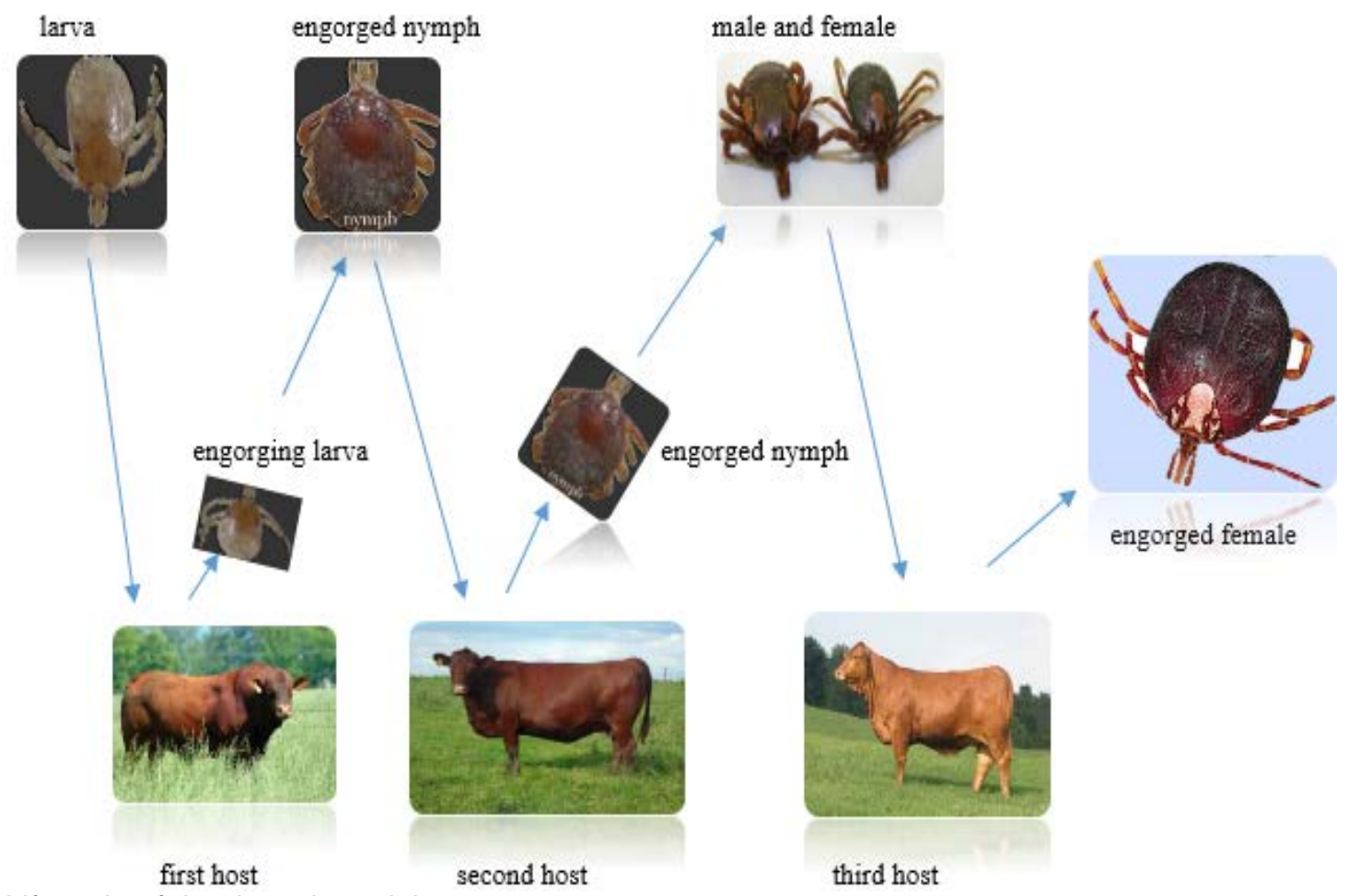

Figure 2 Lifecycle of the three-host tick.

The lifecycle of three-host ticks is slow, and takes from six months to several years to complete (modified from Walker et al., 2003).

A tick's habitat is composed of the variety of biotic and abiotic conditions in which it is found. Ticks are adapted to two contrasting components of their habitat, namely the physical environment and their host (Walker et al., 2003). Three-host ticks (such as $A$. hebraeum) spend up to 99\% of their lives off the host (Oliver, 1989; Pfäffle et al., 2013). Ixodid ticks find their hosts by 'questing' on vegetation or by moving near to distant stimuli (Pfäffle et al., 2013). Estrada-Peña et al. (2013) define 'questing' as the process in the lifecycle in which active stages search for the host. This behaviour of seeking for the host is influenced by 
micro- and macroclimatic factors such as temperature and rainfall (Knap et al., 2009). Various studies have confirmed that the developmental stage (moulting) and questing activity of ticks are controlled by climate (Randolph et al., 2002; Perret et al., 2004; Estrada-Peña \& Venzal, 2007). It is known that temperature regulates the developmental rates. For example, in winter, low temperatures inhibit fast development until temperatures rise in the spring (Estrada-Peña \& De la Fuente, 2014). In summer, long periods of high temperatures can promote mortalities of moulting or questing stages. However, large numbers of free-living ticks appear on the vegetation in spring in temperate regions as a consequence of the synchronous hatching of larvae, driven by the rise in temperature after the winter season. This was shown by Nyangiwe et al. (2011) in the province of Eastern Cape, South Africa. They reported large numbers of $R$. (B.) microplus larvae on the vegetation in spring, which outcompeted those of the native tick $R$. (B.) decoloratus in the study area. The temperature, humidity, host availability and vegetation play a pivotal role in the regulation of the tick lifecycle. The types of vegetation in which cattle graze influence the infestation rate of ticks (Marufu et al., 2011).

\section{Acaricide resistance in Rhipicephalus (Boophilus) microplus cattle ticks}

Several studies have reported the resistance of ticks to synthetic acaricides, particularly organophosphate, synthetic pyrethroids and formamidines (amitraz) in the regions in which the cattle tick $R$. (B.) microplus is found (Soberanes-Céspedes et al., 2002; Miller et al., 2005; Alonso-Díaz et al., 2006; Ntondini et al., 2008; Guerrero et al., 2012; Reck et al., 2014; Van Wyk et al., 2016; Vudriko et al., 2016). Ticks of the sub-genus Rhipicephalus (Boophilus) are most frequently associated with selection for resistance to acaricides, particularly $R$. (B.) decolaratus and $R$. (B.) microplus. Unlike the native tick $R$. (B.) decoloratus, which infests cattle, goats, horses, impalas, bushbuck, kudus, zebras, $R$. (B.) microplus is most affected since it is strictly a parasite of cattle and is usually found on other host species if they graze with cattle (Nyangiwe et al., 2013a).

The southern cattle tick $R$. (B.) microplus is a highly adaptable ectoparasite that has become established in nearly all tropical and subtropical regions of the world in which cattle production occurs (Bram et al., 2002; Busch et al., 2014). It is exposed to every application of acaricide, thus promoting the rapidity with which selection for resistance can take place. The resistance of $R$. (B.) microplus to chemical acaricide plays a role to its spread into non-endemic areas (Awa et al., 2015). The rapid spread of $R$. (B.) microplus in South Africa (Tønnesen et al., 2004; Horak et al., 2009; Nyangiwe et al., 2013a; Nyangiwe et al., 2017), Tanzania (Lynen et al., 2008), Zimbabwe (Smeenk et al., 2000; Sungirai et al., 2015) and West Africa (Madder et al., 2007, 2012; Adakal et al., 2013) is one such example. Recently, farmers encountered tick resistance to the use of acaricide in Burkina Faso, Mali and Togo. This resulted in the alarming spread of $R$. (B.) microplus soon after its first discovery in Ivory Coast and Benin (De Clerq et al., 2012; Madder et al., 2012; Adakal et al., 2013). In South Africa, Nyangiwe et al. (2013b) reported on the first record of $R$. (B.) microplus in Namibia. Of the 18 farms surveyed in Namibia, four were positive for $R$. (B.) microplus. The farmers stated that they had bought bulls from South Africa for herd improvement. $R$. (B.) microplus is resistant to multitudes of chemical compounds. This is great concern for its rapid spread. To solve resistance problems, it is necessary to consider alternatives for efficient and safe control of ticks. The use of resistant breeds is an important means of tick control in some countries, although dipping is still required to minimize tick loads.

\section{Climate change, human driving forces, and tick distribution}

Various studies have reported on the issues of global change, climate change, tick distribution and reemergence of TBDs, in particular for Ixodes ricinus, which is Europe's main vector of Borrelia burgdorferi sensu lato, the causative agent of Lyme borreliosis in humans (Guernier et al., 2004; Gray et al., 2009; Keesing et al., 2010; Ogden et al., 2013; Estrada-Peña \& De la Fuente, 2014; Granter et al., 2014; Medlock \& Leach, 2015). Current global changes (for example climate change, deforestation, changes in land use, urbanization, increased trade and travel) affect the cattle industry worldwide, favouring the introduction of ticks and the diseases they transmit into previously free areas (Dantas-Torres, 2015; Kamani et al., 2017; Nyangiwe et al., 2017; Tabor et al., 2017). However, tick species that transmit harmful pathogens in their native ranges seem likely to do the same in new establishments. Tick distributions are known to vary owing to interaction of many aspects, including climatic factors such as temperature and rainfall (Allen et al., 2002; Cumming \& Van Vuuren, 2006). Over the last century, precipitation has risen by roughly $1 \%$ globally and the trend for maximum temperatures shows an increase of $0.88{ }^{\circ} \mathrm{C}$, with minimum temperatures estimated to rise to $1.86{ }^{\circ} \mathrm{C}$ per 100 years (Githeko et al., 2000; Khasnis \& Nettleman, 2005; Intergovernmental Panel on Climate Change (IPCC), 2007; Pfäffle et al., 2013). Temperature alone affects the reproduction and survival rates of tick species directly, in particular the larvae, which require specific conditions, including humidity (Vassallo et al., 2000; IPCC, 2001; Estrada-Peña et al., 2004). The tropical African climate is favourable to 
most major vector-borne disease, including TBDs (Githeko et al., 2000). It is estimated that in the Sahara and semi-arid parts of southern Africa temperatures may rise by $1.6^{\circ} \mathrm{C}$, but equatorial countries such as Cameroon, Kenya and Uganda could experience an increase of $1.4^{\circ} \mathrm{C}$ by 2050 (Githeko et al., 2000). Using a simple climate envelope model and a division of atmospheric research limited-area model (DARLAM), Olwoch et al. (2007) predicted the suitability of present and future climates for the distribution of 30 tick species under the genus Rhipicephalus in Africa. Their findings showed that East Africa and South Africa were the regions that were most at risk of climate-induced changes in tick distribution and TBDs and that more than $50 \%$ of the species they examined showed potential range expansion. However, climate is not always the only factor to consider when investigating the potential drivers of the spread of ticks in a particular region.

Changes in human habitation and settlement patterns, wide-scale movement of humans and the increased transportation of livestock contribute largely to tick distribution and to the pathogens they transmit (Fayer, 2000; Sutherst, 2001; Weiss, 2008; Barré \& Uilenberg, 2010; Pisanu et al., 2010.). Recently TBDs such as bovine babesiosis and anaplasmosis were observed in countries in which they were previously absent (Beugnet \& Marié, 2009; Léger et al., 2013). Using morphological and molecular identification keys, Kamani et al. (2017) confirmed the invasive tick R. (B.) microplus in two states in the south-western region of Nigeria, which shares international borders with Benin. In Benin, the spread of $R$. (B.) microplus has been reported (Madder et al., 2012; De Clercq et al., 2012). Owing to unrestricted movement of livestock for grazing or trade across Nigerian international borders, the introduction of $R$. (B.) microplus is predicted (Kamani et al., 2017). Similarly, A. variegatum, a three-host tick that originated in Africa, was transported to Madagascar, Mascarene Islands and the West Indies at the time of the Atlantic triangular trade. Not only human driving forces contribute to the spread of $A$. variegatum, but the migratory population of cattle egrets (Bubulcus ibis) between the islands complicate the matter as they are the hosts for immature stages of this three-host tick (Pegram et al., 2004; Barré \& Uilenberg, 2010; Estrada-Peña \& Salman, 2013). However, It is difficult to exercise adequate control measures for multi-host ticks owing to the number of hosts on which they feed and their invasive nature.

Distributional changes in ticks are major concerns in tropical and subtropical regions. However, tick distribution is often accompanied by the displacement of native tick species by the invasive species. The invasions of $R$. (B.) microplus in New Caledonia, West Africa, South Africa and Namibia and of $A$. variegatum in the Caribbean through livestock transportation are perfect examples (Madder et al., 2012; Léger et al., 2013; Nyangiwe et al., 2013b; Kamani et al., 2017; Nyangiwe et al., 2017). Rhipicephalus (Boophilus) decoloratus is indigenous and widespread on the African continent (Figure 3), whereas R. (B.) microplus, a parasite of bovid species, was introduced to South Africa by cattle that were imported from Madagascar after the rinderpest epidemic in 1896 (Spicket et al., 2011; Estrada-Peña \& Salman, 2013). In South Africa, several reports have confirmed the displacement of $R$. (B.) decoloratus by $R$. (B.) microplus. It appears that the spread of $R$. (B.) microplus is advancing more quickly than during the previous 100 years where the $R$. (B.) decoloratus was the most abundant tick species (Tønnesen et al., 2004; Horak et al., 2009; Nyangiwe et al., 2013a; Nyangiwe et al., 2017). However, a viable R. (B.) decolaratus / R. (B.) microplus hybrid exists. This was confirmed by two studies in the Eastern Cape in South Africa (Nyangiwe et al., 2013a; Nyangiwe et al., 2017). The slightly shorter lifecycle of $R$. (B.) microplus, and the presence of its larvae on vegetation in winter in the eastern region of the Eastern Cape, while those of $R$. (B.) decoloratus almost disappear (Nyangiwe et al., 2011), may result in $R$. (B.) microplus completing one more lifecycle per year than $R$. (B.) decoloratus. This appears to enhance its chances of displacing $R$. (B.) decoloratus (Nyangiwe et al., $2013 a$ ). However, R. (B.) microplus is advancing more quickly in Africa, and its distribution (Figure 4) is accompanied by outbreaks of Asiatic redwater in regions in which only African redwater had been recorded in the past (Madder et al., 2012; Estrada-Peña \& Salman, 2013).

In South Africa, R. (B.) microplus was recently introduced in the Northern Cape, where Nyangiwe et al. (2017) collected it for the first time in eight of 18 localities. In the Free State province, the tick was recorded for the fourth time, the first being from gemsbok in the north-west of the province (Tonetti et al., 2009), the second from cattle in the north-east (Spickett, 2013), the third from four cattle and a single larva from a dragsample (Horak et al., 2015) and the fourth at one locality in Heilbron (Nyangiwe et al. 2017). The tropical bont tick $A$. variegatum has wider distribution in Africa than the native tick $A$. haebraeum (Figure 5).

Amblyomma hebraeum, commonly known as the South African bont tick, is native to southern Africa (Figure 5). Like other ticks of the genus Amblyomma, the tropical bont tick transmits heartwater, a fatal caused by Ehrlichia ruminantium and $R$. africae, the causative organism of African tick-bite fever (Léger et al., 2013). Amblyomma variegatum is prevalent in more than 30 African countries and has been considered a serious danger to the US cattle industry because it could spread from the Caribbean to the coast of Florida (Barré \& Uilenberg, 2010; Estrada-Peña \& Salman, 2013). This tick has been reported to withstand long periods of time while waiting for a favourable host, namely approximately 20 months for an 
unfed female. Once fed, she can lay about 20000 eggs (Barré \& Garris, 1990; Léger et al., 2013). In addition, $A$. variegatum inhabits a diversity of habitats, from grassy steppes and mountain meadows to wet savannas. This ubiquity, together with its biology, has facilitated its spread outside its native range of Africa (Estrada-Peña et al., 2007). It has colonized several zones from its native range, such as Caribbean, Madagascar, Comoro and Mascarene Islands and Yemen (Barré \& Uilenberg, 2010). However, A. variegatum is now considered the second most invasive tick species after $R$. (B.) microplus (Barré \& Uilenberg, 2010).

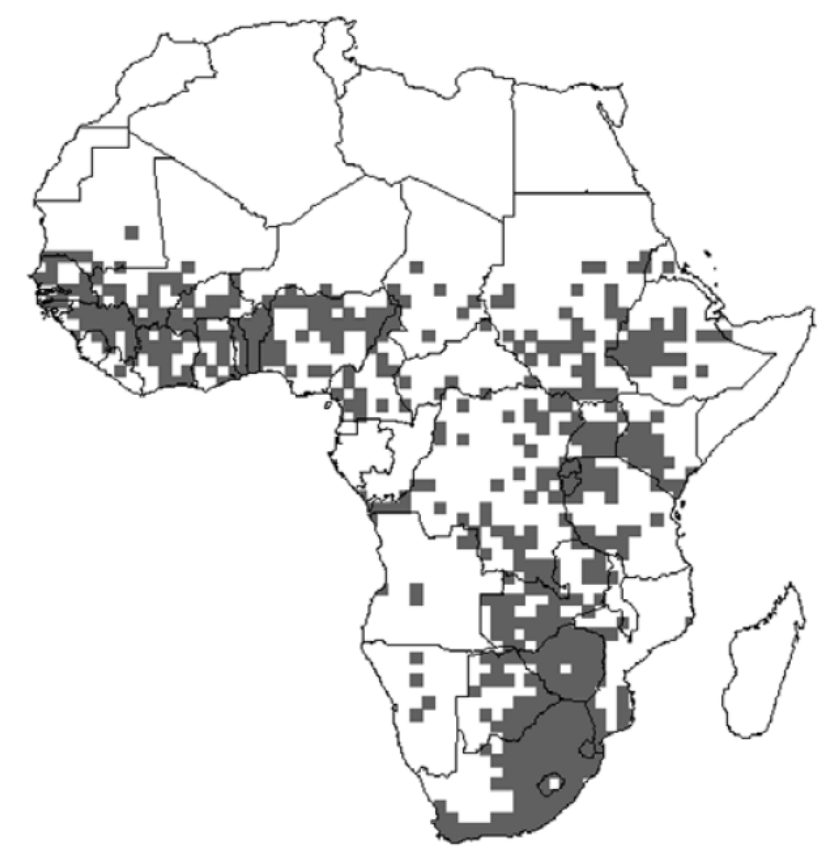

Figure 3 Geographic range of the indigenous tick Rhipicephalus (Boophilus) decoloratus in Africa. (Source: Walker et al., 2003)

Despite its spread, it is being displaced in many localities by the invasive tick $R$. (B.) microplus.

Concerns about the further spread of ticks to the continent have arisen from modelling the preferred climate niche of the tick (Estrada-Peña et al., 2007). A. variegatum is adapted to a wide range of climatic conditions in its native distribution range (Beati et al., 2012). Large cattle egrets are reported to compound its spread, in particular between the islands (Pegram et al., 2004). Tick control for tropical cattle ticks has always been difficult, with accompanying acaricide resistance, but little attention has been paid to the huge potential of medicinal plants with acaricidal properties that are locally available (Mondal et al., 2013). On the other hand, Mapholi et al. (2014) have suggested a genomics approach towards tick control using a singlenucleotide polymorphism (SNP). Genomic selection using SNP markers is regarded as a powerful new tool for genetic selection, which could assist farmers in making decisions on host genetic resistance to ticks (HGRT). However, to control livestock diseases by exploiting genetic information, in-depth knowledge of genome variations is required (Ibeagha-Awemu et al., 2008; Mapholi et al., 2014; Mapholi et al., 2016). 


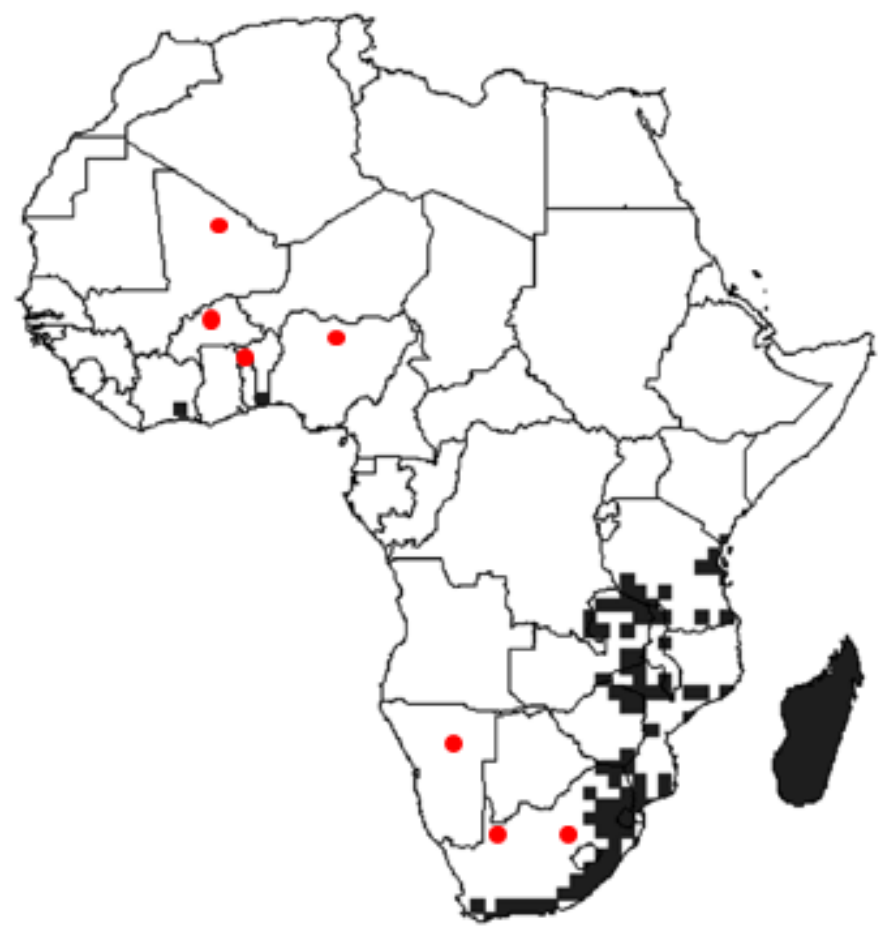

Figure 4 Geographic range of the invasive cattle tick Rhipicephalus (Boophilus) microplus in Africa, with recent observations (red cycle) of the tick in West Africa, Namibia and South Africa.

(Source: Adakal et al., 2017, Nyangiwe et al., 2013b, Nyangiwe et al., 2017)
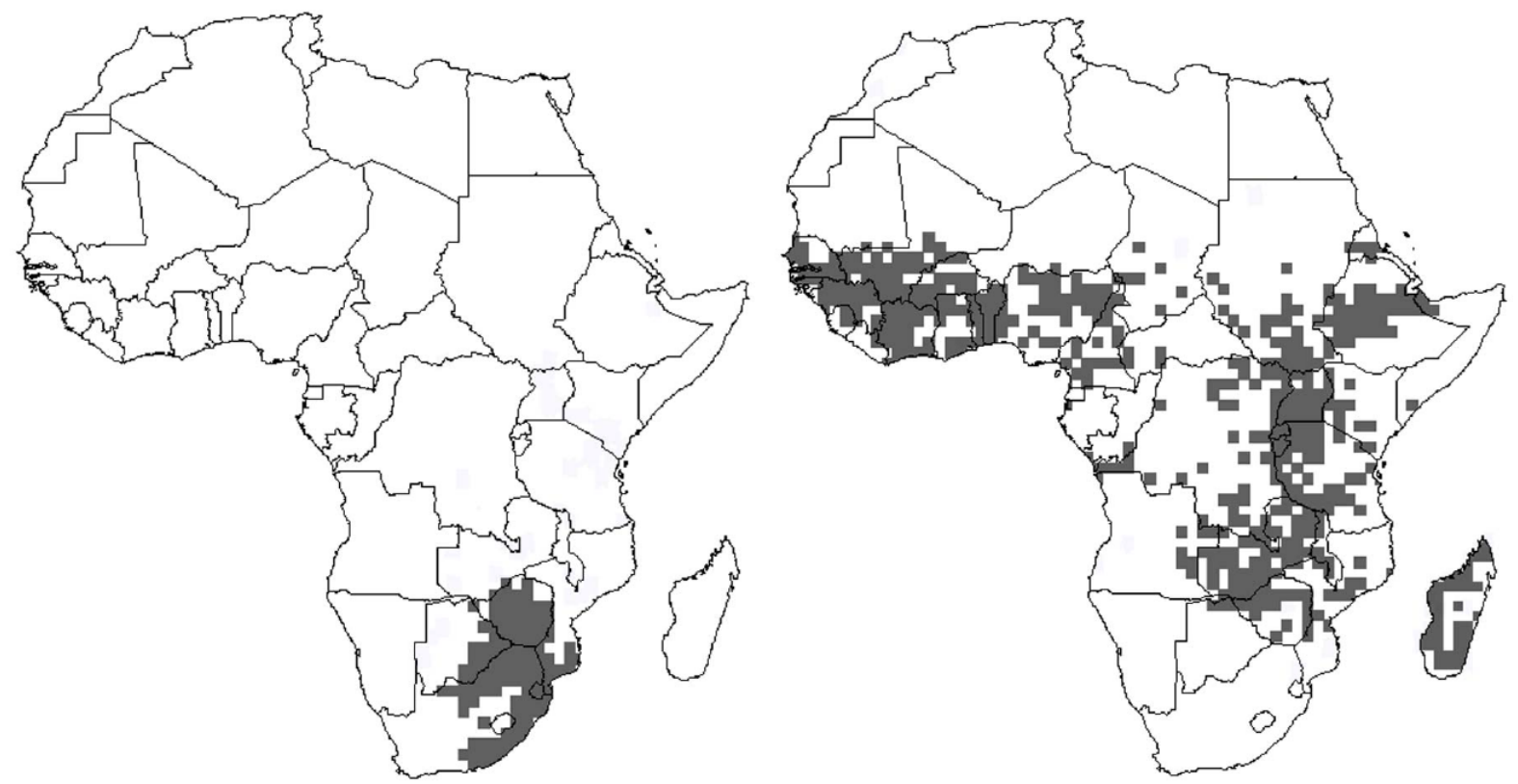

Figure 5 Geographic range of Amblyomma hebraeum (left) and Amblyomma variegatum (right) in Africa. (Source: Walker et al., 2003)

For the epidemiology of heartwater disease and identification of the vector, these ticks occur together only in Zimbabwe.

\section{Conclusions}

Climate change is central to the spread and establishment of new tick species in non-endemic areas. Such establishments promote an increase in tick densities and spatial range, which can lead to higher 
prevalence of TBDs. In tandem with climatic factors, large-scale movements of humans and their animals play a role in speeding up the introduction of novel tick species and the diseases they transmit. Of the two tropical cattle tick species, $R$. (B.) microplus has the propensity to express acaricide resistance, which may contribute to the rapid spread of this species. On the other hand, $A$. variegatum is driven more by transhumance, climate trends and unpredictable movements of cattle egrets than by acaricide resistance. However, more awareness campaigns about the risks of transporting animals from native areas to new territories are required. This could be achieved if government implemented regulations that would avoid unrestricted cattle movement from one region to another and emphasize the involvement of veterinary services for animal transfer.

\section{Acknowledgments}

All the authors of the manuscript acknowledge and thank their universities and institutes.

\section{Authors' Contributions}

All the authors contributed from the onset of the manuscript and approve of the final version.

\section{Conflict of Interest Declaration}

The authors have no conflict of interest to declare.

\section{References}

Abbas, R.Z., Zaman, M.A., Colwell, D.D., Gilleard, J. \& Iqbal, Z., 2014. Acaricide resistance in cattle ticks and approaches to its management: the state of play. Vet. Parasitol. 203, 6-20.

Adakal, H., Biguezoton, A., Zoungrana, S., Courtin, F., De Clercq, E.M. \& Madder, M., 2013. Alarming spread of the Asian cattle tick Rhipicephalus microplus in West Africa - another three countries are affected: Burkina Faso, Mali and Tsogo. Exp. Appl. Acarol. 61, 383-386.

Aguilar-Tipacamu, G., Rosario-Cruz, R., Miller, R.J, Guerrero, F.D., Rodriguez-Vivas, R.I. \& Garcia-Vazquez, Z., 2011. Phenotype changes inherited by crossing pyrethroid susceptible and resistant genotypes from the cattle tick Rhipicephalus (Boophilus) microplus. Exp. Appl. Acarol. 54, 301-311.

Ahmed, J., Alp, H., Aksin, M. \& Seitzer, U., 2007. Current status of ticks in Asia. Parasitol Res. 101, 159-162.

Allen, A.P., Brown, J.H. \& Gillooly, J.F., 2002. Global biodiversity, biochemical kinetics, and the energetic-equivalence rule. Sci. 297, 1545-1548.

Alonso-Díaz, M.A., Rodriguez-Vivas, R.I., Fragoso-Sanchez, H. \& Rosario-Cruz, R., 2006. Resistencia de la garrapata Boophilus microplus a los ixodicidas. Arch. Med. Vet. 38, 105-114.

Awa, D.N., Adakal, H., Luogbou, N.D.D., Wachong, K.H., Leinyuy, I. \& Achukwi, M.D., 2015. Cattle ticks in Cameroon: Is Rhipicephalus (Boophilus) microplus absent in Cameroon and the Central African region? Ticks. Tick. Borne. Dis. 6, 117-122.

Barker, S.C. \& Murrell, A., 2004. Systematics and evolution of ticks with a list of valid genus and species names. Parasitol. 129, 15-36.

Barré, N. \& Garris, G.I., 1990. Biology and ecology of Amblyomma variegatum (Acari: Ixodidae) in the Caribbean: Implications for regional eradication program. J. Agric. Entomol. 7, 1-9.

Barré, N. \& Uilenberg, G., 2010. Spread of parasites transported with their hosts: Case study of two species of cattle tick. Rev. Sci. Tech. Off. Int. Epiz. 29, 149-160.

Bazarusanga, T., Geysen, D., Vercruysse, J. \& Madder, M., 2007. An update on the ecological distribution of Ixodid ticks infesting cattle in Rwanda: country wide cross-sectional survey in the wet and the dry season. Exp. Appl. Acarol. 43, 279-291.

Beati, L., Patel, J., Lucas-Williams, H., Adakal, H., Kanduma, E.G., Tembo-Mwase, E., Krecek, R., Merins, J.W., Alfred, J.T. \& Kelly, S., 2012. Phylogeograph and demographic history of Amblyomma variegatum (Fabricius) (Acari: Ixodidae), the tropical bont tick. Vect. Born. Zoonot. Dis. 12, 512-525.

Beugnet, F. \& Marié, J.L., 2009. Emerging arthropod-borne diseases of companion animals in Europe. Vet. Parasitol. 163, 298-305.

Bock, R., Jackson, L., De Vos, A. \& Jorgensen, W., 2004. Babesiosis of cattle. Parasitol. 129, 247-269.

Bram, R.A., George, J.L., Reichard, R.E. \& Tabachnick, W.J., 2002. Threat of foreign arthropod-borne pathogens to livestock in the United States. J. Med. Entomol. 39, 405-416.

Bush, J.D., Stone, N.E., Nottingham, R., Araya-Anchetta, A., Lewis, J., Hochhalter, C., Giles, J.R., Gruendike, J., Freeman, J., Buckmeier, G., Bodine, D., Duhaime, R., Miller, R.J., Davey, R.B., Olafson, P.U., Scoles, G.A. \& Wagner, D.M., 2014. Widespread movement of invasive cattle fever ticks (Rhipicephalus microplus) in southern Texas leads to shared local infestations on cattle and deer. Parasit \& Vect. 7, 188-203.

Constantinoiu, C.C., Jackson, L.A., Jorgensen, W.K., Lew-Tabor, A.E., Piper, E.K. \& Mayer, D.G., 2010. Local immune response against larvae of Rhipicephalus (Boophilus) microplus in Bos taurus indicus and Bos taurus taurus cattle. Int. J. Parasitol. 40, 865-875.

Cumming, G. \& Van Vuuren, D., 2006. Will climate change affect ectoparasites species ranges? Global Ecol. Biogeogr. $15,486-497$.

Dantas-Torres, F., 2015. Climate change, biodiversity, ticks and tick-borne diseases: The butterfly effect. Int. J. Parasitol. Parasites. Wildl. 4, 452-61. 
De Castro, J.J., 1997. Sustainable tick and tick-borne disease control in livestock improvement in developing countries. Vet. Parasitol. 71, 77-97.

De Clercq, E.M., Vanwambeke, S.O., Sungirai, M., Adehan, S., Lokossou, R. \& Madder, M., 2012. Geographic distribution of the invasive cattle tick Rhipicephalus microplus, a country-wide survey in Benin. Exp. Appl. Acarol. $58,441-452$.

D'Haese, L., Penne, K. \& Elyn, R., 1999. Economics of theileriosis control in Zambia. Trop. Med. Int. Health. 4, 49-57.

Dold, A.P. \& Cocks, M.L., 2001. Traditional veterinary medicine in the Alice district of the Eastern Cape Province, South Africa: Research in action. S. Afr. J. Anim. Sci. 97, 375-379.

Estrada-Peña, A. \& De la Fuente, J., 2014. The ecology of ticks and epidemiology of tick-borne viral diseases. Antivir. Res. 108, 104-128.

Estrada-Peña, A. \& Salman, M., 2013. Current limitations in the control and spread of ticks that affect livestock: A review. Agric. 3, 221-235.

Estrada-Peña, A. \& Venzal, J.M., 2007. Climate niches of tick species in the Mediterranean region: Modelling of occurrence data, distributional constraints, and impact of climate change. J. Med. Entomol. 44. 1130-1138.

Estrada-Peña, A., Horak, I.G. \& Petney, T., 2008. Climate changes and suitability for the ticks Amblyomma hebraeum and Amblyomma variegatum (Ixodidae) in Zimbabwe (1974-1999). Vet. Parasitol. 151, 256-267.

Estrada-Peña, A., Martinez, J.M., Acedo, C.S., Quilez, J. \& Del Cacho, E., 2004. Phenology of the tick, Ixodes ricinus, in its southern distribution range (central Spain). Med. Vet. Entomol. 18, 387-397.

Estrada-Peña, A., Pegram, R.G. \& Venzal, J.M. 2007. Using invaded range data to model the climate suitability for Amblyomma variegatum (Acari: Ixodidae) in the New World. Exp. Appl. Acarol. 41, 203-214.

Estrada-Peña, A., Ruiz-Fons, F., Acevedo, P., Gortazar, C. \& De la Fuente, J., 2013. Factors driving the circulation and possible expansion of Crimean-Congo haemorrhagic fever virus in the western Palearctic. J. Appl. Microbiol. 114, 278-286.

Fayer, R., 2000. Global change and the emerging infectious diseases. J. Parasitol. 86, 1174-1181.

Frans, J., 2000. Final report, integrated control of ticks and tick-borne diseases (ICTTD). p.4. http://www.uu.nl/tropical.ticks.

Frisch, J.E., 1999. Towards a permanent solution for controlling cattle ticks. Int. J. Parasitol. 29, 57-71.

Ghosh, S., Azhahianambi, P. \& De la Fuente, J., 2006. Control of ticks of ruminants, with special emphasis on livestock farming systems in India: Present and future possibilities for integrated control - a review. Exp. Appl. Acarol. 40, 49-66.

Githeko, A.K., Lindsay, S.W., Confalonieri, U.E. \& Patz, J.A., 2000. Climate change and vector-borne diseases: A regional analysis. Bull. Wor. Heal. Organ. 78, 1136-1147.

Granter, S.R., Bernstein, A. \& Ostefeld, R.S., 2014. Of mice and men: Lyme disease and biodiversity. Perspect. Biol. Med. 57, 198-207.

Gray, J.S., 2008. Ixodes ricinus seasonal activity: implications of global warming indicated by revisiting tick and weather data. Int. J. Microbiology. 298, 19-24.

Gray, J.S., Dautel, H., Estrada-Peña, A., Kahl, O. \& Lindgren, E., 2009. Effect of climate change on ticks and tick-borne diseases in Europe. Interdiscip. Perspect. Infect. Dis. http://dx. doi.org/10.1155/2009/593232.

Guernier, V., Hochberg, M.E. \& Guégan, J.F., 2004. Ecology drives the worldwide distribution of human diseases. PLoS Biol. 2, 740-746.

Guerrero, F.D., Lovis, L. \& Martins, J.R., 2012. Acaricides resistance mechanisms in Rhipicephalus microplus. Rev. Bras. Parasitol. Vet. 21, 1-6.

Guglielmone, A.A., Robbins, R.G., Apanaskevich, D.A., Petney, T.N., Estrada-Peña, A., Horak, I.G., Shoa, R. \& Barker, S.C., 2010. The Argasidae, Ixodidae and Nutalliellidae (Acari: Ixodida) of the world: a list of valid species names. Zootaxa. 2528, 1-28.

Horak, I.G., Nyangiwe, N., De Matos, C. \& Neves, L., 2009. Species composition and geographic distribution of ticks infesting cattle, goats and dogs in a temperate and a subtropical coastal region of south-eastern Africa. Onderstepoort J. Vet. Res. 76, 263-278.

Horak, I.G., Fourie, L.J., Heyne, H., Walker, J.B. \& Needham, G.R., 2002. Ixodid ticks feeding on humans in South Africa: with notes on preferred hosts, geographic distribution, seasonal occurrence and transmission of pathogens. Exp. Appl. Acarol. 27, 113-126.

Horak, I.G., Jordaan, A.J., Nel, P.J., Van Heerden, J., Heyne, H. \& Van Dalen, E.M., 2015. Distribution of endemic and introduced tick species in Free State Province, South Africa. J. S. Afr. Vet. Assoc. 86, 1-9. https://doi. org/10.4102/jsava.v86i1.1255

Ibeagha-Awemu, E.M., Kgwatalala, P., Ibeagha, A.E. \& Zhao, X., 2008. A critical analysis of disease-associated DNA polymorphisms in the genes of cattle, goat, sheep, and pig. Mam. Gen. 19, 226-245.

IPCC, 2001. Climate change 2001: Impacts, adaptation \& vulnerability. Edited by J.J. McCarthy, O.F. Canziani, N.A. Leary, D.J. Dokken \& K.S. White. Cambridge University Press, Cambridge, UK, pp 1000.

IPCC, 2007. Climate change 2007: Synthesis report. In: R.K. Pachauri \& A. Reisinger (eds). Contribution of working groups I, II and III to the Fourth Assessment Report of the Intergovernmental Panel on Climate Change. IPCC, Geneva, p 85.

Jensenius, M., Fournier, P.E., Kelly, P., Myrvang, B. \& Raoult, D., 2003. African tick bite fever. Lancet. Infect. Dis. 3, 557564.

Jongejan, F. \& Uilenberg, G., 2004. The global importance of ticks. Parasitol. 129, 3-14. 
Jonsson, N.N., 2006. The productivity effects of cattle tick (Boophilus microplus) infestation on cattle, with particular reference to Bos indicus cattle and their crosses. Vet. Parasitol. 137, 1-10.

Jonsson, N.N., Bock, R.E. \& Jorgensen, W.K., 2008. Productivity and health effects of anaplasmosis and babesiosis on Bos indicus cattle and their crosses, and the effects of differing intensity of tick control in Australia. Vet. Parasitol. 137, 1-9.

Kahl, O., Gern, L., Eisen, L. \& Lane, R.S., 2002. Ecological research on Borrelia burgdorferi sensu lato: terminology and some methodological pitfalls. In: J.S. Gray, O. Kahl, R.S. Lane \& G. Stanek (eds). Lyme borreliosis: Biology, epidemiology and control. CABI, New York, pp. 29-46.

Kamani, J., Apanaskevich, D.A., Gutiérrez, R., Nachum-Biala, Y., Baneth, G. \& Harrus, S., 2017. Morphological and molecular identification of Rhipicephalus (Boophilus) microplus in Nigeria, West Africa: a threat to livestock health. Exp. Appl. Acarol. 73, 283-296.

Katiyatiya, C.L.F., Muchenje, V. \& Mushunje, A., 2014. Farmers' perceptions and knowledge of cattle adaptation to heat stress and tick resistance in the Eastern Cape, South Africa. Asian-Austral. J. Anim. Sci. 27, 1663-1670.

Keesing, F., Belden, L.K., Daszak, P., Dobson, A., Harvell, C.D., Holt, R.D., Hudson, P., Jolles, A., Jones, K.E., Mitchell, C.E., Myers, S.S., Bogich, T. \& Ostefeld, R.S., 2010. Impact of biodiversity on the emergence and transmission of infectious diseases. Nat. 486, 647-652.

Khasnis, A.A. \& Nettleman, M.D., 2005. Global warming and infectious disease. Arch. Med. Res. 36, 689-696.

Knap, N., Durmisi, E., Skaksida, A., Korva, M., Petrovec, M. \& Avsic-Zupanic, T., 2009. Influence of climatic factors on dynamics of questing Ixodes ricinus ticks in Slovenia. Vet. Parasitol. 164, 275-281.

Latif, A.A. \& Walker, A.R., 2004. An introduction to the biology and control of ticks in Africa. Tick of veterinary and medical importance Africa. ICTTD.

Léger, E., Vourc'h, G., Vial, L., Christine, C.C., McCoy, K.D., 2013. Changing distributions of ticks: Causes and consequences. Exp. Appl. Acarol. 59, 219-244.

Lew-Tabor, A.E. \& Rodriguez Valle, M., 2016. A review of reverse vaccinology approaches for the development of vaccines against ticks and tick borne diseases. Ticks Tick. Borne. Dis. 7, 573-585.

Lindgren, E. \& Jaenson, T.G.T., 2006. Lyme Borreliosis in Europe: Influences of climate and climate change, epidemiology, ecology and adaptation measures. WHO Regional Office for Europe, Copenhagen.

Lodos, J., Boue, O., De la Fuente, J.A., 2000. Model to simulate the effect of vaccination against Boophilus ticks on cattle. Vet. Parasitol. 87, 315-326.

Lynen, G., Zeman, P., Bakuname, C., Di Giulio, G., Mtui, P., Sanka, P. \& Jongejan, F., 2008. Shifts in the distributional changes of Boophilus ticks, in Tanzania: Evidence that a parapatric boundary between Boophilus microplus and Boophilus decoloratus follows climate gradients. Exp. Appl. Acarol. 44, 147-164.

Machado, M.A., Azevedo, A.L.S., Teodoro, R.L., Pires, M.A., Peixoto, M.G.C.D., De Freitas, C., Prata, M.C.A., Furlong, J., Da Silva, M.V.G.B., Guimarães, S.E.F., Regitano, L.C.A., Coutinho, L.L., Gasparin, G. \& Verneque, R.S., 2010. Genome wide scan for quantitative trait loci affecting tick resistance in cattle (Bos taurus $\mathrm{x}$ Bos indicus). BMC. Genomics 11, 280.

Madder, M., Thys, E., Geysen, D., Baudoux, C. \& Horak, I., 2007. Boophilus microplus ticks found in West Africa. Exp. Appl. Acarol. 43, 233-234.

Madder, M., Thys, E., Achi, L., Touré, A. \& De Deken, R., 2011. Rhipicephalus (Boophilus) microplus: A most successful invasive tick species in West Africa. Exp. Appl. Acarol. 53, 139-145.

Madder, M., Adehan, S., De Deken, R., Adehan, R. \& Lokossou, R., 2012. New foci of Rhipicephalus microplus in West Africa. Exp. Appl. Acarol. 56, 385-390.

Mapholi, N.O., Maiwashe, A., Matika, O., Riggio, V., Bishop, S.C., MacNeil, M.D., Banga, C., Taylor, J.F. \& Dzama, K., 2016. Genome-wide association study of tick resistance in South African Nguni cattle. Ticks Tick. Borne. Dis. 7 , 487-497.

Mapholi, N.O., Marufu, M.C., Maiwashe, A., Banga, C.B., Muchenje, V., MacNeil M.D., Chimonyo, M. \& Dzama, K., 2014. Towards a genomics approach to tick (Acari: Ixodidae) control in cattle: A review. Ticks Tick-Borne Dis. 5, 475-483.

Mapiye, C., Chimonyo, M., Dzama, K, Raats, J.G. \& Mapekula, M., 2009. Opportunities for improving Nguni cattle production in the smallholder farming systems of South Africa. Livest. Sci. 124, 196-204.

Marcelino, I., De Almedia, A.M., Ventosa, M., Pruneau, L., Meyer, D.F., Martinez, D., Lenfrancois, T., Vachiery, N. \& Coelho, A.V., 2012. Tick borne disease in cattle: Applications of proteomics to develop new generation vaccines. J. Proteom. 75, 4232-4250.

Martinez, M.L., Machado, M.A., Nascimento, C.S., Silva, M.V.G.B., Teodoro, R.L., Furlong, J., Prata,M.C.A., Campos, A.L., Guimarães, M.F.M., Azevedo, A.L.S., Pires, M.F.A. \& Verneque, R.S.. 2006. Association of BoLA-DRB3.2 alleles with tick (Boophilus microplus) resistance in cattle. Gen. Mol. Res. 5, 513-524. 
Marufu, M.C., Chimonyo, M., Mans, B.J. \& Dzama, K., 2013. Cutaneous hypersensitivity responses to Rhipicephalus tick larval antigens in pre-sensitized cattle. Ticks Tick. Borne. Dis. 4, 311-316.

Marufu, M.C., Qokweni, L., Chimonyo, M. \& Dzama, K. 2011. Relationships between tick counts and coat characteristics in Nguni and Bonsmara cattle reared on semiarid rangelands in South Africa. Ticks Tick. Borne. Dis. 2,172-177.

Medlock, J.M. \& Leach, S.A., 2015. Effect of climate change on vector-borne disease risk in the UK. Lancet. Infect. Dis. 15, 721-730.

Miller, R.J., Davey, R.B. \& George, J.E., 2005. First report of organophosphate -resistant Boophilus microplus (Acari: Ixodidae) within the United States. J. Med. Entomol. 42, 912-917.

Mondal, D.B., Sarma, K. \& Saravanan., 2013. Upcoming of the integrated tick control program of ruminants with special emphasis on livestock farming system in India. Ticks Tick. Borne. Dis. 4, 1-10.

Muchenje, V., Dzama, K., Chimonyo, M., Raats, J.G. \& Strydom, P.E., 2008. Tick susceptibility and its effects on growth performance and carcass characteristics of Nguni, Bonsmara and Angus steers raised on natural pasture. Anim. Int. J. Anim. Biosc. 2, 298-304.

Norval, R.A. \& Horak, I.G., 2004. Vectors: ticks. In: Infectious diseases of livestock. Edited by J.A.W. Coetzer \& R.C. Tustin: Oxford University Press, Cape Town, South Africa. pp. 3-42.

Ntondini, Z., Van Dalen, E.M.S.P. \& Horak, I.G., 2008. The extent of acaricide resistance in 1-, 2- and 3-host ticks on communally grazed cattle in the eastern region of the Eastern Cape Province. J. S. Afr. Vet. Assoc. 79, 130-135.

Nyangiwe, N., Goni, S., Hervé-Claude, L.P., Ruddat, I. \& Horak, I.G. 2011. Ticks on pastures and on two breeds of cattle in the Eastern Cape province, South Africa. Onderstepoort J. Vet. Res. 78, 1-9.

Nyangiwe, N., Harrison, A. \& Horak, I.G., 2013a. Displacement of Rhipicephalus decoloratus by Rhipicephalus microplus (Acari: Ixodidae) in the Eastern Cape Province, South Africa. Exp. Appl. Acarol. 61, 371-382.

Nyangiwe, N., Matthee, C., Horak, I.G. \& Matthee, S., 2013b. First record of the pantropical blue tick Rhipicephalus microplus in Namibia. Exp. Appl. Acarol. 61, 503-507.

Nyangiwe, N., Horak, I.G., Van der Mescht, L. \& Mattee, S. 2017. Range expansion of the economically important Asiatic blue tick, Rhipicephalus microplus, in South Africa. J. S. Afr. Vet. Assoc. 88, https://doi.org/10.4102/jsava.v88i0.1482

Ogden, N.H., Barker, I.K., Beauchamp, G., Brazeau, S., Charron, D.F., Maarouf, A. \& Lindsay, L.R., 2006. Invstigation of ground level and remote-sensed data for habitat classification and prediction of survival of Ixodes scapularis in habitats of southeeastern Canada. J. Med. Entomol. 43, 403-414.

Ogden, N.H., Bigras-Poulin, M., Hanicová, K., Maarouf, A., O’Callaghan, C.J. \& Kurtenbach, K. 2008. Projected effects of climate change on tick phenology and fitness pf pathogens transmitted by the North American tick Ixodes scapularis (Acari: Ixodidae). J. Theor. Biol. 254, 621-632.

Ogden, N.H., Mechai, S. \& Margos, G., 2013. Changing geographic ranges of ticks and tick-borne pathogens: Drivers, mechanisms and consequences for pathogen diversity. Front. Cell. Infect. Microbiol. 3, 46.

Oliver, J.H., 1989. Biology and systematics of ticks (Acari: Ixodidae). Ann. Rev. Ecol. Syst. 30, 397-430.

Olwoch, J.M., Van Jaarsveld, A.S., Scholtz, C.H. \& Horak, I.G., 2007. Climate change and the genus Rhipicephalus (Acari: Ixodidae) in Africa. Onder. J. Vet. Res. 74, 45-72.

Pegram, R.G., Indar, L., Eddi, C. \& George, J., 2004. The Caribbean Amblyomma Program: Some ecologic factors affecting its success. Ann. New York Acad. Sci. 1026, 302-311.

Perret, J.L., Rais, O. \& Gern, L., 2004. Influence of climate on the proportion of Ixodes ricinus nymphs and adults questing in a tick population. J. Med. Entomol. 41, 361-365.

Pfäffle, M., Littwin, N., Muders, S.V. \& Petney, T.N., 2013. The ecology of tick-borne diseases. Int. J. Parasitol. 43, 1059-1077.

Pisanu, B., Marsot, M., Marmet, J., Chapuis, J.L., Reale, D. \& Vourc'h., 2010. Introduced Siberian chipmunks are more heavily infested by ixodid ticks than are native bank voles in a subburban forest in France. Int. J. Parasitol. 40, 1277-1283.

Porto Neto, L.R., Jonsson, N.N., D'Occhio, M.J. \& Barendse, W., 2011. Molecular genetic approaches for identifying the basis of variation in resistance to tick infestation in cattle. Vet. Parasitol. 180, 165-172.

Rajput, Z.I., Hu, S., Chen, W., Arijo, A.G. \& Xiao, C., 2006. Importance of ticks and their chemical and immunological control in livestock. J. Zhejiang Univ. Sci. B. 7, 912-21.

Randolph, S.E., Green, R.M., Hoodless, A.N. \& Peacey, M.F., 2002. An emperical quantitative framework for the seasonal population dynamics of the tick Ixodes ricinus. Int. J. Parasitol. 32, 979-989.

Reck, J., Klafke, G.M., Webster, A., Dall'Agnol, B., Scheffer, R., Souza, U.A., Corassini, V.B., Vargas, R., dos Santos, J.S. \& de Souza Martins, J.R., 2014. First report of fluazuron resistance in Rhipicephalus microplus: A field tick population resistance to six classes of acaricides. Vet. Parasitology. 201, 128-136.

Smeenk, I., Kelly, P.J., Wray, K., Musuka, G., Trees, A.J. \& Jongejan, F., 2000. Babesia bovis and B. bigemina DNA detected in cattle and ticks from Zimbabwe by polymerase chain reaction. J. S. Afr. Vet. Assoc. 71, 21-24. 
Soberanes-Céspedes, N., Santamaria-Vargas, M., Fragoso-Sanches, H. \& Garcia-Vazques, Z., 2002. Primer caso de Resistencia al amitraz en la garrapata del ganado Boophilus microplus en México (First case reported of amitraz resistance in the cattle tick Boophilus microplus in Mexico). Téc Pecu. Méx. 40, 81-92.

Socolovschi, C., Matsumoto, K., Marie, J.L, Davoust, B., Raoult, D. \& Parola, P., 2007. Identification of rickettsiae, Uganda and Djibouti. Emerg. Infect. Dis. 13, 1508-1510.

Spickett, A.M., 2013. Ixodid ticks of major economic importance and their distribution in South Africa, Agri Connect, Pretoria. ISBN: 978-0-9922220-4-8. (Monograph).

Sungirai, M., Madder, M., Moyo, D.Z., De Clercq, P. \& Abatih, E.N., 2015. An update on the ecological distribution of the Ixodidae ticks in Zimbabwe. Exp. Appl. Acarol. 66: 269-280.

Süss, J., Klaus, C., Gerstengarbe, F.W. \& Werner, P.C., 2008. What makes ticks tick? Climate change, ticks, and tickborne diseases. J. Travel. Med. 15, 935-945.

Sutherst, R.W., 2001. The vulnerability of animal and human health to parasites under global change. Int. J. Parasitol. 31, 933-948.

Tabor, A.E., Ali, A., Rehman, G., Rocha Garcia, G., Zangirolamo, A.F., Malardo, T. \& Jonsson, N.N., 2017. Cattle tick Rhipicephalus microplus-host interface: A review of resistant and susceptible host responses. Front. Cell. Infect. Microbiol. 7, 506-524.

Terkawi, M.A., Thekisoe, O.M.M., Katsande, C., Latif, A.A., Mans, B.J., Matthee, O., Mkize, N., Mabogoane, N., Marais, F., Yokoyama, N., Xuan, X. \& Igarashi, I., 2011. Serological survey of Babesia bovis and Babesia bigemina in cattle in South Africa. Vet. Parasitol. 182, 337-342.

Tonetti, N., Berggoetz, M., Rühle, C., Pretorius, A.M. \& Gern, L., 2009. Ticks and tick-borne pathogens from wildlife in the Free State Province, South Africa. J. Wildl. Dis. 45, 437-466.

Tønnesen, M.H., Penzhorn, B.L., Bryson, N.R., Stoltsz, W.H. \& Masibigiri, T., 2004. Displacement of Boophilus decoloratus by Boophilus microplus in the Soutpansberg region, Limpopo Province, South Africa. Exp. Appl. Acarol. 32, 199-208.

Van Wyk, R.D., Baron, S. \& Maritz-Olivier, C., 2016. An integrative approach to understanding pyrethroid resistance in Rhipicephalus microplus and R. decoloratus ticks. Ticks Tick. Borne. Dis. 7, 586-594.

Vassallo, M., Paul, R.E.L. \& Perez-Eid, C., 2000. Temporal distribution of the annual nymphal stock of Ixodes ricinus ticks. Exp. Appl. Acarol. 24, 941-949.

Vudriko, P., Okwee-Acai, J., Tayebwa, D.S., Byaruhanga, J., Kakooza, S., Wampande, E., Omara, R., Muhindo, J.B., Tweyongyere, R., Owiny, D.O., Hatta, T., Tsuji, N., Umemiya-Shirafuji, R., Xuan, X., Kanameda, M., Fujisaki, K. \& Suzuki, H., 2016. Emergence of multi-acaricide resistant Rhipicephalus ticks and its implication on chemical tick control in Uganda. Parasit. Vect. 9, 4-13.

Walker, A.R., Bouattour, A., Camicas, J.L., Estrada-Pena, A., Horak, I.G., Latif, A., Pegram, R.G. \& Preston, P. M., 2003. Ticks of domestic animals in Africa, A guide to identification of species. Bio. Rep. 1, 35-57.

Weiss, L., 2008. Zoonotic parasitic disease: emerging issues and problems. Int. J. Parasitol. 38, 1209-1210.

Willadsen, P., 2006. Tick control: Thoughts on a research agenda. Vet. Parasitol. 138, 16-18.

World Organization for Animal Health [OIE], 2008. Manual of diagnostic tests and vaccines OIE, Paris. Bovine babesiosis: http://www.oie.int/eng/normes/mmanual/2008/pdf/2.04.0. 